\title{
Success Determinants of Private Labels in Nigeria: A Study of Selected Motorcycle Private Labels
}

\author{
Moses C. Olise (PhD) \\ Anayo D. Nkamnebe (PhD)
}

Department of Marketing, Nnamdi Azikiwe Universtiy, Awka, Nigeria

Doi: 10.19044/esj.2018.v14n13p14 URL:http://dx.doi.org/10.19044/esj.2018.v14n13p14

\section{Abstract}

This study examined the success determinants of private labels in Nigeria: A study of selected motorcycle private labels. The study, modelled variables like market context (rate of expansion), private label phenomenon, retailer- manufacturer relationship (Manufacturers willingness to supply), brand development, sales performance, price and government regulation to ascertain how they have influenced the success of private labels in the motorcycle industry using the Incremental and Radical Innovation and Cumulative Change and Punctuated Equilibrium theories. The study adopted a descriptive survey research design that aimed to determine the relationship between the independent variables and dependent variable in a population. The population of this study was made up of 2977 registered members of motorcycle private label owners in Anambra and Enugu states. A sample of 353 was determined for the study using Taro Yamane formula. A structured questionnaire was administered to 353 respondents but only 348 responded to the questionnaire. The data collected using the questionnaire were analyzed using descriptive statistics like frequency, mean and standard deviation; and also inferential statistics such as factor analysis and regression analysis. All analysis was conducted using SPSS version 23. Findings show that: private label phenomenon, retailer manufacturer relationship, Sales Performance, price, and government regulation are significant success determinants of private labels in the motorcycle industry. While, private label market context and brand development are not significant but they have positive relationship with successful private labels in the motorcycle industry. Based on the findings of this study, the following recommendations were made: With respect to Private Label Market Context, the study recommends that there is a need for the development of advanced private label program in terms of quality and market share by the ministry regulating trade and commerce in Nigeria. The entrepreneurs need to sustain the Private Label Phenomenon since it has a direct and positive relationship with successful private labels and 
it has also been confirmed that private label phenomenon has significant influence on the success of motorcycle Private Labels among others.

Keywords: Private labels (PLs), Principal component analysis, Motorcycle spares parts

\section{Introduction}

A decline in organized public transport systems has led to rapid growth in non-conventional means of public transport, initially provided by minibuses and shared taxi/vans, and more recently by commercial motorcycles (Kumar, 2011). According to Kumar (2011) it is paradoxical that in developing cities where vehicle ownership is low, dependence on public transport is high, whereas the financial condition and performance of all forms of governmentorganized public transport, either state or privately owned, are in decline. This situation has forced people and the market to develop creative solutions to address daily travel needs. Increased demand for commercial motorcycles stepped up importation of commercial motorcycles and consequently increased competition among vendors. As the market grows, the vendors now develop Private Labels in the motorcycle markets in Nigeria in their effort to attract and retain customers.

Private Labels (PLs) have been conceptualized by researchers from various stand points and the researchers (Wettsten, Brosig, Glauben, Hannf \& Loy, 2009; Dick, Jain, \& Richardson, 1995) are in agreement that Private Labels refers to retailer-owned brands, store-brands or products owned and/or licensed for exclusive use by businesses for distribution in their respective markets and have emerged as one of the key realities of contemporary global marketing system. Some of the prominent motorcycle private label owners in Nigeria include: (1) Louis Cater Ind. Ltd. (2) K.C. Sanya (KC. Akoson Investment Company Ltd) (3) Ogbuawa Special Motor Cycle Spare Parts (4) Innoson Nig Ltd (5) Ngobros Nig Ltd (6) Kofec Ltd (7) Muteki Ltd (8) Gazza Supper Industries Ltd (9) JKS Nig Ltd (10) Cosbes Ltd (11) Otugo Special Motor Cycle Parts Ltd (12) IBK Nig Ltd (13) Mesco (14) Chinelson Ltd (15) Mitsuba Ltd. (16) Suaco (17) Fine bird (18) Double Power (Ugo Best) Nig Ltd (19) Domez author ltd. (20) Oyazed Tire Ltd. (21) Diamond Rings Ltd (22) Eugo International Ltd (23) Banuel Nig Ltd etc. Arguably, private labels are beginning to penetrate the Nigerian market across product categories in the last two decade due to global competition among national and international brands. According to Olise, Nkamnebe, Ukenna and Okoli (2014), in the emerging markets, such as Nigeria, the private labels phenomenon since the 1980s has been noticed among the Igbo entrepreneurs following their high entrepreneurial drive, yet their activities have been underreported in mainstreams private labels discourse. 
The success of private labels in Nigeria is devoid of empirical evidence, but can only be substantiated by the perceived growing trend and increasing development of private labels market. Reasons have been given in the literature for the development of private labels which include control and high margins associated with private labels (Connor \& Peterson, 1996; Dobson, 1998; Gabrielsen, Steen and Sorgard, 2001; Terpstra \& Sarathy, 1994). Accordingly, other literatures have stated that the major reason for the development of private labels is to gain control. This includes control of channel members, control of profit margin, and control of relationship with customers (Altintas, Kilic, Senol \& Isin, 2010; Tamilia, Corriveau \& Arguedas, 2000; Terpstra \& Sarathy, 1994).

In tracing the historical antecedence of motorcycles private labels market in Nigeria, a cursory observation in key markets in the country, such as Nkwo market Nnewi, Onitsha new parts market both in Anambra state and Ogbete main market \& coal camp market both in Enugu state give eloquent testimony to the significant incursions motorcycle private labels are making in the markets, thereby carving out a niche and market share for themselves. These market territories which traditionally belonged to the national brands, are now being strongly contested by the presence of private labels in different categories. Thus warrant an empirical probe into private labels particularly the motorcycles private labels market in Nigeria.

\section{Statement of the Problem}

Over the past decade, the private label phenomenon is gaining dominant position in Nigeria particularly in the motorcycle industry. Consequently, the perceived proliferation and dominance of Private Labels in the motorcycle markets in Nigeria is beginning to arouse some research interest. Historically, motorcycle brands were dominated by national brands of Asian origin, Notably Suzuki, Kawasaki, Honda, Yamaha, etc. that compete among themselves for the ever increasing market in the country. Recently, Private Labels such as Ogbuawa, Louis Carter, K.C. Sanya, Day Long etc. started to emerge and now seems to dominate the market.

Understanding the success factors could help in better understanding how to grow Nigeria brands for the obvious economic benefits. Successful private labels in this context are measured by the number of years that the private labels have lasted in the market without going into extinction. Incidentally, there is a limited research in this area of discourse, which creates wide knowledge gap with obvious theory and practical implications. However, studies on private labels are many with scholars approaching it from various stand points in the developed western market context of Europe and America. They have investigated private label market context, private label phenomenon, sales performance, brand development and retailer- 
manufacturer relationship (Collins-Dodd \& Lindley, 2003; Dick, Jain \& Richardson, 1995; Grabrielsen, et al 2001; Song, 2009). In some other studies, drivers of private labels were also predicted to be determined by brand development (Wettsten et al, 2009), market share- sales volume (Chimhundu, 2011; Hoch, Montgomery and Park, 2002; Wettsten, et al, 2009), Manufacturers willingness to supply (Song, 2009), government regulation (Aworemi and Ilori, 2008), price and rate of expansion (Wettstein, et al, 2009), while in Nigeria, there is limited empirical study on private labels which creates a situation of inadequate empirical evidence to measure the success of private labels in the motorcycles private labels market.

The western dominance of literature is confirmed by Song (2009) as he sustained that the development of private labels varies notably from Western to non-Western markets. The former market has a very advanced private label program in terms of quality and market share, while the latter is at an early stage of development. As a result, the majority of the research has been drawn from the Western market.

The inadequacy of empirical evidence on why private labels are successful in the Nigeria market and western dominance of literature in the private labels phenomenon arouse a research interest, therefore, warranting an empirical probing in this study area to ascertain success determinants of private labels in Nigeria particularly in the motorcycle industry. From available literature to the researcher, there is dearth of such study in the Nigeria. This literature and empirical evidence gap is found missing in the Nigeria motorcycle private labels market.

\section{Objectives of the Study}

The main objective of this study is to ascertain the success determinants of private labels in Nigeria: A study of selected motorcycle private labels. Specifically the study intends to:

1. Ascertain the effect of market context on the success of motorcycle Private Labels in Nigeria.

2. Find out the influence of private label phenomenon on the success of motorcycle Private Labels in Nigeria.

3. Determine the influence of retailer- manufacturer relationship on the success of motorcycle Private Labels in Nigeria.

4. Determine the effect of brand development on the success of motorcycle Private Labels in Nigeria.

5. Ascertain the effect of sales performance on the success of motorcycle Private Labels in Nigeria.

6. Determine the influence of price on the success of motorcycle Private Labels in Nigeria. 
7. Ascertain the influence of government regulation on the success of motorcycle Private Labels in Nigeria.

\section{Hypotheses}

The following null hypotheses were tested in the study:

\section{Hypothesis One}

Ho1: Market context has no significant influence on the success of motorcycle Private Labels in Nigeria.

\section{Hypothesis Two}

Ho2: Private label phenomenon has no significant influence on the success of motorcycle Private Labels in Nigeria.

\section{Hypothesis Three}

Ho3: Retailer- manufacturer relationship has no significant influence on the success of motorcycle Private Labels in Nigeria.

\section{Hypothesis Four}

Ho4: Brand development has no significant influence on the success of motorcycle Private Labels in Nigeria.

\section{Hypothesis Five}

Ho5: Sales performance has no significant influence on the success of motorcycle Private Labels in Nigeria.

\section{Hypothesis Six}

Ho6: Price has no significant influence on the success of motorcycle Private Labels in Nigeria.

\section{Hypothesis Seven}

Ho7: Government regulation has no significant influence on the success of motorcycle Private Labels in Nigeria.

\section{Empirical Review}

There are a number of empirical literatures on private labels with scholar viewing the subject from different standpoints. For example; Yokoyama, Silva and Piato (2014) examined why some manufacturers decide to become private label suppliers and how this benefits them - by exploring the opportunities and challenges of private label suppliers. Findings revealed that the adoption of private label strategy improved the suppliers' manufacturing abilities. Monnot, Reniou and Parguel (undated) examined consumer responses to elimination of over-packaging on private label products using ANCOVA and mediation analyses. Finding shows that eliminating over-packaging does have an influence on mimic private labels' image, particularly on perceived quality, convenience and environmental friendliness. It also revealed that this influence negatively transfers to purchase intention for mimic private labels through lower perceived quality and convenience. Beneke (2010) investigated the perceptions of fast 
moving private label brands in the South African grocery food sector. Successful positioning of these brands has been achieved globally, most notably in developed markets. However, in a South African context this does not appear to be the case. To this end, research has been undertaken in order to better understand the current position these brands occupy in the minds of South African consumers. Included in the study is the consideration of critical branding elements such as trust, availability, pricing, packaging, etc. The knowledge gained through this research should ideally facilitate the process of advancing private label brand research in an academic context and improving brand positioning, increasing market share and optimizing profit extracted from private label brands in a managerial context. Bozhinova (2013) examined retailers' private labels as a competitive strategy of the present day. It specifically investigated the relationship between the degree of concentration of retailing and the share of private label goods and also factors facilitating private label goods to penetrate the market are outlined, and the benefits for retailers, manufacturers and consumers in developing countries were investigated. Sirieix, Delanchy, Remaud and Zepedad (2011) investigates (1) two focus groups consumers' perceptions about sustainable labels versus other labels, such as origin or nutrition labels, and (2) consumers' reactions to combinations of different sustainable claims or labels. Findings indicate that there is interest in combining different claims into a single label. The results also indicate the importance of familiarity, trust and, fit between combinations of labels as well as between a label associated with a brand. While the combination of certain labels can enhance the value of a food product, their study also indicates that other label combinations can detract from a label's value. Kundu, Banerjee and Das (2013), examined factors that may influence consumers' intention to purchase private label food product in a state in Malaysia. Factors examined are extrinsic factors which include 'perceived price', 'packaging', 'advertisement' and 'store image'; intrinsic factors (i.e. 'perceived quality', 'perceived risk' and 'perceived value') and consumers' attitudes (in terms of trust, familiarity and perceived economic situation). Using independent t-test, ANOVA, correlation analysis and multiple linear regressions. Result shows that 'perceived value' becomes prominent in consumers' purchasing of private label brand food product, followed by other factors. Almost all independent variables are associated with purchase intention towards private label brand food products. The most significant factor that influencing consumers' purchase intention towards private label food products are 'consumers' attitude' and 'perceived price'. Consumers' past purchasing experience with the private label food products may also influence their perception towards price, packaging, store image and trust of those products. Song (2009) carried out an investigation of manufacturing Chinese private label. Their study examined factors leading to retailers 
developing private label in non-Western markets such as China, Eastern Europe, and Africa, using a semi-structured interviews with a group of ten private label suppliers and three retail consultants. The findings revealed that different factors associated with manufacturing private labels exist between the Western and non-Western markets. Nyengerai, Jaravaza, Mukucha, Chirimubwe and Manjoro (2013). Examined the Determinants of Perception towards Private Label in Zimbabwe: The Role of Familiarity, Store Image, Demographic Factors and Consumer Characteristics using stepwise multiple linear regression. Findings revealed that there exist a significant and positive effect on private label perception and store image perception. Cuneo, Milberg, Benavente and Palacios (2014) examined country-level market structure factors-retail distribution structure, retailer typology, and logistic structure-to understand the differential success of private labels across countries. The results indicate that these factors help explain the dispersion pattern of private labels penetration across 46 countries and that the distribution structure has the largest effect on private labels share, followed by the logistic structure and retailer typology in particular global discounters. Martos-Partal (2012) investigated national brand manufacturers' innovations, and analyses the relationship between innovation and the market share of private labels in the consumer packaged-goods industry using logistic regression methods adapted to the resource allocation context, manufacturers' innovation strategy has a negative impact on the market share of private labels in two specific market conditions. Gabrielsen, Steen and Sørgard (2001) carried out an analysis of the effects of private label entry on national brand prices in the Norwegian food sector using a dynamic price regression. The results suggest that introduction of a private label typically leads to higher prices on national brands. However, they observe a large heterogeneity in price responses. When they also apply a dynamic panel data approach, the same picture emerges. They find heterogeneity with both negative and positive significant price responses. However, they also establish that highly distributed and ranked products are typically more influenced by private label entry than less distributed and ranked products ("weaker" national brands). They also find some support in their data that more successful private labels entry - as measured by the private labels market share - have typically a larger impact on the national brand prices. Bontemps, Orozco and Réquillart (2008) examined the relationships between national brand prices and the development of private labels, using home-scanned data from a consumer survey reporting purchases for 218 food products. In a significant number of cases (144 out of 218 ), they observe a positive correlation ( $89 \%$ ) between national brand price and purchases of private labels. When controlling for changes in the products quality, they still find a positive relation between private label development and national brand prices. Thus, the change in the national brand product 
characteristics only partly explains the increase in the national brand prices. Furthermore, the price reactions of national brands differ according to the type of private labels they are facing. Finally, they demonstrate that the development of private labels has less effect on the prices of second-tier brands than prices of the leading brand. Kundu and Kar (2012), examined the scope of branding private labels and its influence on customer loyalty and repurchase intent. Kundu and Kar (2012) highlighted that a huge population base and a growing domestic market for food products, the non-branded perishable items like fruits and vegetable $(\mathrm{F} \& \mathrm{~V})$, and even the branded food industry was homing in converting Indian consumers to their relevant lines. There came the usage of private labels and branding it to project store image. Busch and Bain (2004) highlighted how rapidly food retailers are becoming more global and oligopolistic and are busy creating their own brands. Furthermore, Burch and Lawrence (2005) highlighted a control reallocation in accountability concerning agri-food supply chain on the ploy of control amid the organization as regards type of agri-food production essential, place of assembly, volume and standards associated with it. They emphasized the presence of intense competition for customer patronage which changed the position of private branding and its self space in their outlets. D'silva and Bhuptani (2010) in their study analyzed brand positioning factors and highlighted its impact on customer loyalty for maximizing sales. Keller and Lehmann (2005) highlighted the profitability factor in selling comparable generic and branded merchandise to establish the value of a consumer to a retail firm. Wettstein et al. (2009) highlighted consumer perception towards private labels and analyzed its scope in developing customer loyalty. The study measured the difference in customers' repurchasing behaviour between national and private labels. However, repurchasing behaviour does not establish the significance of brand loyalty. Erciset, Schroder, Goedertier and Van (2010) emphasized the significance of implementing strategies and building store loyalty. Their study highlighted three factors in building customer loyalty namely: satisfaction effect, trust value perception and store image. Erhun, Babalola and Erhun (2001) established the factors that have contributed to the preponderance of counterfeit drugs in Nigeria despite the laws. The results revealed that drug laws were adequate falling short only in their implementation. The task forces were rated as ineffective arising from corruption, communication gaps, lack of adequate funds, and lack of vehicles among others.

Private Label literature reviewed revealed a number of insightful and robust findings that created a knowledge and literature gap to be filled. Firstly, the available literature showed a western dominance of private label literature. Secondly, some of the studies reviewed have deeply dwelt on the following areas: Fast Moving Consumer Goods (FMCG)-private label from the manufacturer's perspectives (Altintas, Kilic, Senol, \& Isin, 2010; Gomez \& 
Benito, 2008; Song, 2009), consumer perspective of private labels (Miranda \& Joshi, 2003; Sinha \& Batra, 1999). Thirdly, following the classification of Private Labels by Altintas et al (2010) that Private Labels can be investigated from three perspectives: (1) consumer-based and related studies; (2) National brand and private label comparisons; (3) manufacturer-related studies. However, there seems to be a paucity of studies on Private Label retailers' perspective particularly in the motorcycles industry. This study therefore fills the literature and knowledge gap by examining the success determinants of private labels in Nigeria: A study of selected motorcycle private labels.

\section{Theoretical Framework}

This study revolves around four interrelated biological and non biological theories. They are Incremental and Radical Innovation and Cumulative Change and Punctuated Equilibrium theories. Incremental and Radical Innovation are non biological theories while Cumulative Change and Punctuated Equilibrium or what has been described by Chimhundu (2011) as gradualist and punctuated evolutionary theories are biological theories. The proponents of the theories are Gersick, (1991)- Incremental and Radical Innovation, Darwin (1957)- Cumulative Change and Eldridge and Gould (1972)- Punctuated Equilibrium. However, the study is built on two related theories - Radical Innovation and Punctuated Equilibrium theories.

According to Gersick, (1991), the tenets of the Incremental and Radical Innovation theories holds that organizations evolve through relatively long periods of stability in their basic patterns of activity that are punctuated by "relatively short bursts of fundamental change. Tushman and Romanelli (1994) examined four major organizations and found that technology evolves through relatively long periods of incremental change punctuated by relatively rare innovations that radically improve the state of the art. Most innovations (Incremental) simply build on what is already there, requiring modifications to existing functions and practices, but some innovations (Radical) change the entire order of things, making obsolete the old ways (Van de Ven, Polley, Garud \& Venkataramen, 1999). The Private Label is explained by the radical innovation theory in a situation where the national brands of Asian origin, Notably Suzuki, Kawasaki, Honda, Yamaha, etc. that compete among themselves for the ever increase market in the country are made obsolete and suddenly replaced by Private Labels such as Ogbuawa, Louis Carter, K.C. Sanya, Day Long etc and now seems to dominate the market.

Again the application of Darwin (1957) and Eldridge and Gould (1972) theories derived from outside the business field to marketing is not unusual. There is a history of application of biological models in the field of marketing, dating as far back as 1957 (Chimhundu, 2011). As cited by Chimhundu (2011), the product life cycle model was one of the first to be introduced and cemented 
into the marketing field (Katsanis \& Pitta, 1995). Gradualist and punctuated equilibrium theories also have their roots in biological models. The gradualist theory of change has its origins in Darwin's model of evolution, which takes evolution as a slow, cumulative, incremental process. The theory became pervasive; was later applied to a variety of fields ranging from geological erosion to skill acquisition and can also be used to explain the change that takes place in organisational settings (Chimhundu, 2011; Gersick, 1991).

Eldridge and Gould (1972) proposed a different view of evolution termed punctuated equilibrium, thus challenging Darwinian gradualism. They postulated that lineages experience little change over most of their history, and that new species arise through abrupt, revolutionary punctuations. According to Gersick (1991), similar, empirically derived theories in a variety of fields have echoed this theory. For instance, in the field of innovation, Abernathy and Utterback (1982) have made a contrast between evolutionary and radical innovation in industry. In the field of organisational management, Tushman and Romanelli (1994) adapted the punctuated equilibrium model, empirically tested it and found that it was consistent with organisational change. The results of their study demonstrated that "revolutionary transformation, as predicted by the punctuated equilibrium model, is a principal means by which organisations fundamentally alter their systems, strategies and structures"). In this regard, the essence of punctuated equilibrium theory is that "relatively long periods of stability (equilibrium), are punctuated by compact periods of qualitative, metamorphic change (revolution)" (Gersick, 1991 in addition, Katsanis and Pitta (1995) applied punctuated equilibrium theory to product management and showed that the theory is useful in explaining changes that the product management system has been experiencing, and changes that it continues to undergo.

Applying these theories to the present study - success determinants of private labels in Nigeria: A study of selected motorcycle private labels - is fundamental. The Tenets of the theories holds that successful private labels can follow the Gradualist and punctuated equilibrium process. In the former, - Gradualist equilibrium process- the success of the motorcycles private labels in the market place can either be a slow, cumulative, incremental process over a period of time while in the later punctuated equilibrium process - the success of the motorcycles private labels in the market place can be a revolutionary transformation, as predicted by the punctuated equilibrium model as a result of the alteration of the dominance of the national or manufacturers brands. In the final analysis, success of the motorcycles private labels in the market place can follow, on the one hand, the punctuated equilibrium theory which involves a rapid change over a short period of time (revolution), which is followed by a state of equilibrium. The period of equilibrium can either experience no change at all or can be characterized by slow/gradual, incremental change. The 
process can also be a one-off or can happen over and over again, over time. Again, success of the motorcycles private labels in the market place can follow on the other hand the gradualist theory that involves consistently slow/gradual, incremental change throughout. In this regard, the issue of what pattern motorcycles private labels success adopts in the market place in relation to national brands can best be explained by the Radical Innovation theory and punctuated equilibrium theory.

Fig. 1. Conceptual/Theoretical Framework

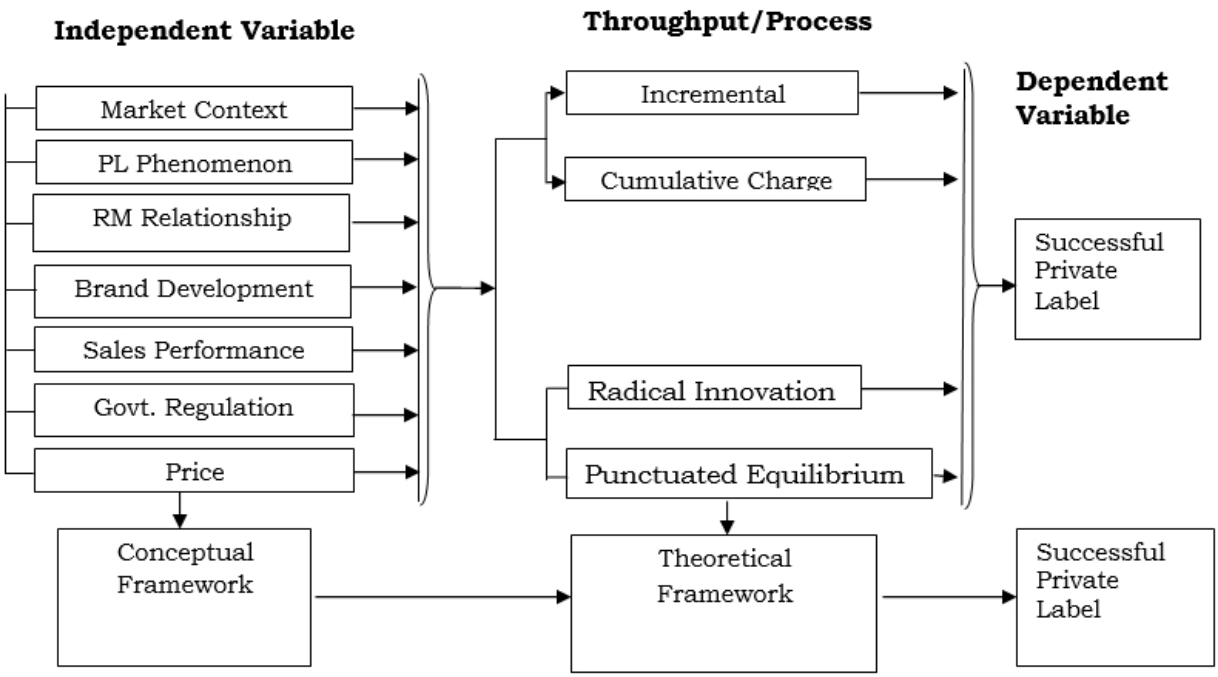

Source: Authors' Conceptualization

\section{Methodology}

Area of Study

The study was carried out in southeast Nigeria, specifically in Anambra and Enugu States. The states are significant to this study because they are major economic hubs in Nigeria with respect to motorcycle private labels. They have motorcycle private labels in their numbers scattered all over the markets as a result of the increasing demand for commercial motorcycles and rising population of people that operate in the industry. Some of the cities include: Nkwo market Nnewi, Onitsha new parts market both in Anambra state and Ogbete main market \& coal camp market both in Enugu state: Nnewi plays a leading role as a centre for the manufacturing of cars, assembly and distribution of motorcycles and spare-parts in Nigeria and as such other economic activities take place in the area. It is the second largest economic hub of Anambra state after Onitsha market and one of the largest in West Africa. The inhabitants are predominantly traders who are into various kinds of economic activities and manufacturers of auto and auto spare parts.

Onitsha plays a leading role as a centre for the importation, manufacturing, distribution, sales/services of all sorts of goods and services in 
Nigeria and as such other economic activities take place in the area. It is the largest economic hub of Anambra state and the second largest in West Africa after Ariaria, Aba in Abia state. The inhabitants are predominantly traders who are into various kinds of economic activities like importation, manufacturing, distribution, sales/services of various kinds of goods and services including assembly and distribution of motorbikes and spare-parts in Nigeria.

Ogbete and Coal camp are both in Enugu metropolis. Again, they are the major hubs of economic activities in the state. The major occupation of the inhabitants of the area is trading. Although they have other occupational engagements like: food processing, craft, teaching in schools and colleges, civil service etc. the area also has a good number of traders who are into various kinds of economic activities like importation, distribution, sales/services of various kinds of goods and services including assembly and distribution of motorbikes and spare-parts in Nigeria.

\section{Population of the Study}

The population or unit of analysis of the study consist of motorcycle Private Label retailers/owners in Nigeria. A non-probability sampling purposive sampling - was used to select Anambra State and Enugu state as the population because of the dominance of Private Label motorcycle retailers/owners in the areas. The researcher was able to obtain the records of Private Label motorcycle retailers/owners with registered business names through the Anambra State and Enugu state Automobile Manufacturers and Importers Association. A total number of 2977 Private Label motorcycleretailers/owners were obtained from the records of the Anambra State and Enugu state Automobile Manufacturers and Importers Association.

\section{Sample Size and Sampling Procedure}

The sample size for the study was obtained using Taro Yamani formula. The formula is stated thus:

$$
\begin{aligned}
& \mathrm{n}= \\
& =\quad \text { sample } \\
& \mathrm{N}=\text { population } \\
& \mathrm{e}=\quad \text { Margin of error }(5 \% \text { or } 0.05) \\
& \text { I }=\text { Constant }
\end{aligned}
$$

Substituting in the above formula:

$\mathrm{n}$

$$
\begin{aligned}
& =\frac{2977}{1+2977(0.05)^{2}} \\
& =\frac{2977}{1+2977(0.0025)}
\end{aligned}
$$




$=\frac{2977}{8.4425}$
$=352.6$
$=353$

For the purpose of allocation of sample stratum, the researcher adopted R. Kumaison's formula. Below is the R. Kumaisons formula for sample size distribution:

$\mathrm{nh}=\underline{\mathrm{nNh}}$

Where $\mathrm{n}$

Where $\mathrm{n} \quad=\quad$ Total sample size

$\mathrm{Nh}=$ The number of items in each stratum in the population

$\mathrm{N}=$ Population size

nh $=$ The number of units allocated to

each stratum

$\mathrm{n} \quad=\quad 353$

Table 1: Distribution of Private Label retailers/owners by Population and Sample

\begin{tabular}{|c|c|c|}
\hline Economic areas of operation & Population & Sample \\
\hline Nkwo market Nnewi & 1650 & 196 \\
\hline Onitsha new parts market & 951 & 113 \\
\hline Ogbete main market & 127 & 15 \\
\hline Coal camp market & 249 & 29 \\
\hline Total & 2977 & 353 \\
\hline
\end{tabular}

Source: Computation from Field Survey, 2016

The instrument used for the data collection was the questionnaire which was designed and administered to motorcycle Private Label retailers/owners that registered their business with the Anambra State and Enugu state Automobile Manufacturers and Importers Association in the economic hubs of the state. The questionnaire was titled success determinants of private labels in Nigeria: A study of selected motorcycle private labels. The questionnaire has two sections. Section A and Section B. Section A sought information on demographic profile of the respondents. Section B was made up of items designed to elicit information relating to the success determinants of private labels in Nigeria: A study of selected motorcycle private labels. Using a close ended questions and a five (5) point likert summative scale question of Very Great Extent (VGE) 5 points; Great Extent (GE) 4 points; Undecided (U) 3 points; Some Extent (SE) 2 points; and No Extent (NE) 1 point. Out of the 353 questionnaires distributed only 348 were dully completed and returned. 


\section{Method of Data Analysis}

Data collected were analyzed using descriptive statistics (frequencies, percentages, mean, and standard deviation) and the inferential statistics such as factor analysis, t-test statistics and the linear regression model. The demographic profiles were processed using descriptive statistics. Objectives one to seven were subjected to factor analysis for the purpose of data reduction in order to avoid having spurious result. Thereafter the seven objectives were processed using descriptive statistics (like percentages, mean and standard deviation) and the regression model of the Ordinary Least Square (OLS). Ttest and F-test statistics were used to test the hypotheses of the study and the overall fitness of the model. All the analysis were done using SPSS version 23. Linear regression model of the Ordinary Least Square (OLS) approach was used to analyse the objectives in order to ascertain the influence and also determine the relationship between the independent variables and dependent variable in the conceptualised model of the study. The use of Ordinary Least Square (OLS) is informed by the fact that under normality assumption for $\alpha_{\mathrm{i}}$, the Ordinary Least Square (OLS) estimator is normally distributed and are said to be best, unbiased linear estimator (Gujarati and Porter, 2008).

Thus, the model of this study is stated as follows:

The functional form of the model is

$\mathrm{SPL}=\mathrm{f}(\mathrm{MC}, \mathrm{PLP}, \mathrm{RMR}, \mathrm{BD}, \mathrm{SP}, \mathrm{P}, \mathrm{GR})$

The mathematical form of the model is

$\mathrm{SPL}=\beta_{0}+\beta_{1} \mathrm{MC}+\beta_{2} \mathrm{PLP}+\beta_{3} \mathrm{RMR}+\beta_{4} \mathrm{BD}+\beta_{5} \mathrm{SP}+\beta_{6} \mathrm{P}+\beta_{7} \mathrm{GR}$

The econometric form of the model is

$\mathrm{SPL}=\beta_{0}+\beta_{1} \mathrm{MC}+\beta_{2} \mathrm{PLP}+\beta_{3} \mathrm{RMR}+\beta_{4} \mathrm{BD}+\beta_{5} \mathrm{SP}+\beta_{6} \mathrm{P}+\beta_{7} \mathrm{GR}+\alpha_{\mathrm{i}} \ldots .$. (3)

Where; SPL $=$ Successful Private Labels proxied by number of years of existence

$\mathrm{MC}=$ Market Context

PLP = Private Label Phenomenon

RMR = Retailer- Manufacturer Relationship

$\mathrm{BD}=$ Brand Development

$\mathrm{SP}=$ Sales Performance

$\mathrm{P} \quad=$ Price

GR = Government Regulation

$\beta_{0}=$ Intercept of the model

$\beta_{1}-\beta_{7}=$ Parameters of the model

$\alpha_{i}=$ Stochastic error term

\section{Data presentation and analysis}

This section deals with the presentation and analysis of data collected from the field of study. The aim is to present the data in an interpretable form so that the variables of the study can be well understood. 


\section{Demographic Profile of the Respondents}

Table 2: Distribution of Respondents According to Gender

\begin{tabular}{cccc}
\hline Variable & Frequency & Percent $(\%)$ & Cumulative (\%) \\
\hline Male & 346 & 99.4 & 99.4 \\
Female & 2 & .6 & 100.0 \\
Total & 348 & 100.0 & \\
\hline
\end{tabular}

Source: Field Survey, 2016

Table 2 shows that $99.4 \%$ of the respondents are males while $0.6 \%$ of the respondents are females.

Table 3: Distribution of Respondents According to Age

\begin{tabular}{cccc}
\hline Variable & Frequency & Percent $(\%)$ & Cumulative $(\%)$ \\
\hline $18-32$ & 4 & 1.1 & 1.1 \\
$31-40$ & 46 & 13.2 & 14.3 \\
$41-50$ & 152 & 43.7 & 58.0 \\
$51-60$ & 88 & 25.3 & 83.3 \\
$61-70$ & 58 & 16.7 & 100.0 \\
Total & 348 & 100.0 & \\
\hline
\end{tabular}

Source: Field Survey, 2016

As shown in table $3,1.1 \%$ of the respondents are between the ages 1832 years. $13.2 \%$ of the respondents are between the ages of 31-40years. $43.7 \%$ of the respondents are between the ages of 41-50years. $25.3 \%$ of the respondents are between the ages of 51-60year, while $16.7 \%$ of the respondents are between the ages of 61-70years.

Table 4: Distribution of Respondents According to Educational Qualification

\begin{tabular}{cccc}
\hline Variable & Frequency & Percent $(\%)$ & Cumulative (\%) \\
\hline Primary & 11 & 3.2 & 3.2 \\
Secondary & 289 & 83.0 & 86.2 \\
Tertiary & 48 & 13.8 & 100.0 \\
Total & 348 & 100.0 & \\
\hline
\end{tabular}

Source: Field Survey, 2016

From table 4, all the respondents had formal education. 3.2\% of the respondents had primary education, $83.0 \%$ had secondary education while $13.8 \%$ had tertiary education.

Table 5: Distribution of Respondents According to Years of Business Experience in Private labels

\begin{tabular}{cccc}
\hline Variable & Frequency & Percent $(\%)$ & Cumulative $(\%)$ \\
\hline $1-5$ & 81 & 23.3 & 23.3 \\
$6-10$ & 185 & 53.2 & 76.5 \\
$11-15$ & 78 & 22.4 & 98.9 \\
$15-30$ & 4 & 1.1 & 100.0 \\
Total & 348 & 100.0 & \\
\hline
\end{tabular}

Source: Field Survey, 2016 
With respect to business experience in private label, table 5 revealed that $23.3 \%$ of the respondents had 1-5years business experience in private label. 53.2\% had 6-10years business experience in private label. $22.4 \%$ of the respondents had 11-15years business experience in private label, while $1.1 \%$ had 15-30years business experience in private label.

Table 6: Distribution of Respondents According to Marital Status

\begin{tabular}{cccc}
\hline Variable & Frequency & Percent (\%) & Cumulative (\%) \\
\hline Married & 296 & 85.1 & 85.1 \\
Single & 47 & 13.5 & 98.6 \\
Widow/Widower & 5 & 1.4 & 100.0 \\
Total & 348 & 100.0 & \\
\hline
\end{tabular}

Source: Field Survey, 2016

From table $6,85.1 \%$ of the respondents are married. $13.5 \%$ are single while $1.4 \%$ is widow/widower.

Table 7: Distribution According to Respondents Position

\begin{tabular}{cccc}
\hline Variable & Frequency & Percent $(\%)$ & Cumulative (\%) \\
\hline Owner/CEO & 217 & 62.4 & 62.4 \\
Manager & 131 & 37.6 & 100.0 \\
Total & 348 & 100.0 & \\
\hline
\end{tabular}

Source: Field Survey, 2016

With respect to respondents' position, $62.4 \%$ of the respondents are Owner/CEO while $37.6 \%$ are managers.

\section{Regression Analysis Result}

Table 8: Regression Result on success determinants of private labels in Nigeria: A study of selected motorcycle private labels

\begin{tabular}{ccccc}
\hline Model & B & $\begin{array}{c}\text { Std. } \\
\text { error }\end{array}$ & T & Sig. \\
\hline $\begin{array}{c}\text { Constant(C) } \\
\text { Private Label Market Context }\end{array}$ & $\begin{array}{c}25.475 \\
\text { Private Label Phenomenon }\end{array}$ & 0.891 & 28.579 & 0.000 \\
Retailer Manufacturer & 2.956 & 0.364 & 1.098 & 0.273 \\
Relationship & 0.930 & 0.488 & 15.749 & 0.000 \\
Brand Development & 0.526 & 0.503 & 1.991 & 0.047 \\
Sales Performance & 0.689 & 0.062 & 11.143 & 0.025 \\
Price & -1.604 & 0.221 & -7.254 & 0.000 \\
Government Regulation & -0.355 & 0.121 & -2.931 & 0.004 \\
R & 0.929 & & & \\
$\mathrm{R}^{2}$ & 0.863 & & & \\
Adj. $\mathrm{R}^{2}$ & 0.860 & & & 0.000 \\
F-statistic & 331.601 & & & \\
\hline
\end{tabular}




\section{Dependent Variable: Years of Business Experience in Private labels}

To ascertain the determinants of successful private labels in the motorcycle industry the weighted mean of the seven independent variables were regressed on the dependent variable to enable us determine the nature of relationship between the dependent and independent variables, effect/impact of the seven independent variables on the dependent variable, the overall fitness of the model using the F-statistics and probability value and the level of significance of the independent variables in influencing the dependent variables using the t-test and probability value. The table above shows the regression result. Table 8 showed the precision of the model which was analyzed using economic a priori criteria and statistical criteria.

\section{Evaluation based on economic a priori criteria}

Evaluation using this criterion enables us to determine the nature of relationship between the dependent and independent variables. In this case the sign and magnitude of each variable coefficient is evaluated against theoretical or economic a priori criteria/expectations. As shown in the table 8 , it is observed that the regression line has a positive intercept as presented by the constant $(c)=25.475$. This means that if all the variables are held constant or fixed (zero), the success of private labels in the motorcycle industry increases by $25.5 \%$. The result also conforms to the a-priori expectation. This states that the intercept could be positive or negative, so it conforms to the theoretical expectation. Private Label Market Context has a positive relationship with successful private labels. This implies that the Private Label Market Context and successful private labels increases in the same direction. That is to say that Private Label Market Context has a direct and positive relationship with successful private labels. In other words a $1 \%$ increase in Private Label Market Context will bring about a $39.9 \%$ growth in the success of private labels in the motorcycle industry. Private Label Phenomenon has a direct and positive relationship with successful private labels. In other words a $1 \%$ increase in Private Label Phenomenon will bring about a 295.6\% growth in the success of private labels in the motorcycle industry. Retailer Manufacturer Relationship has a direct and positive relationship with successful private labels. As the Retailer Manufacturer Relationship grows it increases the success of private labels in the motorcycle industry. In other words a $1 \%$ increase in Retailer Manufacturer Relationship will bring about a $93.0 \%$ increase in the success of private labels in the motorcycle industry. Brand Development and sales Performance also have direct and positive relationship with successful private labels. Therefore, a $1 \%$ increase in either of them will bring about a $52.6 \%$ and $68.9 \%$ increase in the success of private labels in the motorcycle industry respectively. On the other hand, price and government regulation have inverse relationship. Which implies that price and government 
regulation move in opposite direction with successful private labels. The duo has a negative influence on successful private labels. As price increases successful private labels decreases.

\section{Discussion based on statistical criteria}

In order to evaluate the determinants of successful private labels in the motorcycle industry, the analysis was also done based on statistical criteria by applying the coefficient of determination $\left(\mathrm{R}^{2}\right)$ and the $\mathrm{F}$-test. In general the joint effect of the explanatory variables- independent variables- in the model account for 0.860 or $86.0 \%$ of the variations in the factors influencing successful private labels in the motorcycle industry. This implies that $86.0 \%$ of the variations in the successful private labels are being accounted for or explained by the variations in private label market context, private label phenomenon, retailer manufacturer relationship, brand development, sales performance, price, government regulation. While other independent variables not captured in the model explain just $14 \%$ of the variations in successful private labels in the motorcycle industry.

Five coefficients (private label phenomenon, retailer manufacturer relationship, sales performance, price and government regulation) are significant determinant of successful private labels in the motorcycle industry. Private label market context and brand development are not significant but they have positive relationship with successful private labels in the motorcycle industry.

\section{Summary of Findings}

1. Private Label Market Context has a direct and positive relationship with successful private labels. The descriptive statistics also suggests that market context has influenced the success of motorcycle Private Labels with a grand mean of 4.24. However, from the hypothesis tested, it was revealed that the level of influence by the Market context on the success of motorcycle Private Labels was not significant.

2. Private Label Phenomenon has a direct and positive relationship with successful private labels. The descriptive statistics also suggests that private label phenomenon has influenced the success of motorcycle Private Labels with a grand mean of 3.85. The hypothesis also confirmed that private label phenomenon has significant influence on the success of motorcycle Private Labels.

3. Retailer- manufacturer relationship has significant influence on the success of motorcycle Private Labels. The descriptive statistics suggests that retailer- manufacturer relationship influences the success of motorcycle Private Labels with a grand mean of 4.33. It also has a direct and positive relationship with successful private labels. 
4. Brand Development has a direct and positive relationship with successful private labels. It also has a level of influence on the success of motorcycle Private Labels. However, brand development has no significant influence on the success of motorcycle Private Labels.

5. Sales Performance has a direct and positive relationship with successful private labels. However, sales Performance has a significant influence on the success of motorcycle Private Labels.

6. Price has an inverse relationship with successful private labels. However, both the descriptive statistics and the hypothesis confirmed that. Price has significant influence on the success of motorcycle Private Labels.

7. Government regulation also has an inverse relationship with successful private labels. The descriptive statistics suggests that government regulation has no adequate influenced on the success of motorcycle Private Labels. Yet, government regulation has significant influence on the success of motorcycle Private Labels.

\section{Recommendations}

Based on the findings of this study, the following recommendations are made:

1. With respect to Private Label Market Context, the study recommends that there is need for the development of advanced private label program in terms of quality and market share by the ministry regulating trade and commerce in Nigeria.

2. The entrepreneurs need to sustain the Private Label Phenomenon since it has a direct and positive relationship with successful private labels and it has also been confirmed that private label phenomenon has significant influence on the success of motorcycle Private Labels.

3. The entrepreneurs should also enhance private labels' retailermanufacturer relationship by attracting the manufacturing plant into Nigeria. This will help to create employment, boast the economy and grow private labels in the motorcycle industry.

4. With respect to brand development, though not significant but there is need for the entrepreneurs to improve on Brand Development since it has a direct and positive relationship with successful private labels.

5. There is need for adequate private labels market development by the ministry regulating trade and commerce in Nigeria, this will help to enhance sales performance and improve quality and market share of private labels.

6. With respect to Price, there is need for private label owners/ retailers to be price sensitive because it has been proven to help differentiate private labels concerning price and product diversification compared to competing stores, gain channel efficiency, raise the retailers' income and profits, generate store loyalty and attract high purchase frequency among others. 
7. There should be strong government regulation on private labels because it has been found to have significant influence on the success of motorcycle Private Labels.

\section{References:}

1. Abernathy, W., \& Utterback, J. (1982). Patterns of industrial innovation. In M. Tushman \& W. Moore (Eds.), Readings in the Management of Innovation (pp. 97-108). Boston, MA: Pitman.

2. Altintas, M. H., Kilic, S., Senol, G., \& Isin, F. B. (2010). Strategic objectives and competitive advantages of private label products: manufacturers' perspective. International Journal of Retail and Distribution Management. 38(10), 773-788.

3. Altintas, M.H \& Kilic, S. (n.d). Strategic using of private labels from retailers' perspective in Turkey. Ankara Üniversitesi SBF Dergisi.

4. Aworemi, J. R \& Ilori, M. O. (2008). An evaluation of the performance of private transport companies in selected South-western of Nigeria. African Journal of Business Management, 2(8), 131-137.

5. Beneke, J. (2010). Consumer perceptions of private label brands within the retail grocery sector of South Africa. African Journal of Business Management, 4(2), 203-220.

6. Bozhinova, M. (2013). Private Label - Retailers' Competitive Strategy. Global Journal of Management and Business Research, 13(10), 29-34.

7. Busch, T., \& Ben, B. (2004). An Empirical Investigation of the Spillover Effects of Advertising and Sales Promotions in Umbrella Branding. Journal of Marketing Research, 39, 408-420.

8. Butch, B. \& Lawrence, J. M. (2005). Consumer perceptions of comparative price advertisements. Journal of Marketing Research, 416-427.

9. Chimhundu, R. (2011). Private Label Marketing Performance: An Analysis of Historical Trends Using Theories of Cumulative Change and Punctuated Equilibrium. International Journal of Business and Management, 6(8), 58-65.

10. Collins-Dodd, C. \& Lindley, T. (2003). Store brands and retail differentiation: the influence of store image and store brand attitude on store own brand perceptions. Journal of Retailing and Consumer Services 10 (2003) 345-352.

11. Collins, A. \& Burt, S. (2003). Market Sanctions, Monitoring and vertical coordination with retailer manufacturer relationships: the case of retail brand suppliers, European Journal of Marketing, 37 (5/6): 668-689. 
12. Concha, J. R. (2013). Manufacturer-Dealer Relationships. The Influence of Trust and Commitment to Technological Interface Adoption. Modern Economy, 4, 14-21

13. Connor, J. \& Peterson, E. (1996). Market structure determinants of national brand-private label price difference of manufactured food products. J. Indust. Econom. 40 157-171.

14. Corstjens, M. \& Rajiv L. (2000), "Building store loyalty through store brands," Journal of Marketing Research, 37 (August), 281-91.

15. Cunningham, I. C. M., Hardy, A. P. \& Imperia, G. (1982). Generic Brands Versus National Brands and Store Brands. Journal of Advertising Research. Vol. 22 (5), pp. 25-32.

16. Cuneo, A., Milberg, S. J., Benavente, J. M. \& Palacios-Fenech, J. (2014). The Growth of Private Label Brands A Worldwide Phenomenon? Journal of International Marketing, 72-92.

17. D' Silva, M. \& Bhuptani, R. (2010), Building store loyalty through store brands, Journal of Marketing Research, 37 (3), 281-291.

18. Darwin, C.R. (1876). The origin of species by means of natural selection, or the preservation of favoured races in the struggle for life. John Murray, London; (http://darwin-online.org.uk).

19. Dick, A., Jain, A. \& Richardson, P. (1997), How Consumers Evaluate Store Brands, Pricing Strategy \& Practice, 5/1: 18-24.

20. Dick, A., Jain, A \& Richardson, P. (1995). Correlates of store brand proneness: some empirical observations. Journal of Product \& Brand Management, 4 (4), 15-21.

21. Dobson, P.W., (1998). The Economic Welfare Implications of Own Label Products School of Management. University of Nottingham, Discussion Paper 1998. IV., 1998.

22. Eldredge, N. \& Gould, J.G. (1972). Puntuated Equilibra: An alternative to phyletic gradualism. In Schopf, Thomas. J.M (ed.), Models in Pleobiology, Freman, Cooper and Company, San Francisco, pp. 82-115

23. Erciset, K., Schroder G., Goedertier, F. \& Van. G. (2010). Consumer perceptions of store brands versus national brands. Journal of Consumer Marketing, 22, (4), 223-232.

24. Erhun, W.O., Babalola, O.O. \& Erhun, M.O. (2001). Drug Regulation and Control in Nigeria: The Challenge of Counterfeit Drugs. Journal of Health \& Population in Developing Countries, 4(2):23-34.

25. Gabrielsen, T. S., Steen, F. \& Sǿrgard, L. (2001). Private Label Entry as a Competitive Force? An analysis of price responses in the Norwegian food sector. 
26. Gersick, C. J. G. (1991). Revolutionary change theories: A multilevel exploration of the punctuated equilibrium paradigm. Academy of Management Review, 16(1), 10-36.

27. Gomez, M. \& Benito, N.R. (2008). Manufacturer's characteristics that determine the choice of producing store brands. European Journal of Marketing, 42(2), 154-177.

28. Gomez, M. \& Rubio, N. (2008). Shelf management of store brands: an analysis of manufacturers' perceptions. International Journal of Retailing \& Distribution Management, 36(1), 50-70.

29. Grewal, D., Krishnan, R., Baker, J., \& Borin, N. (1998). The effect of store name, brand name and price discounts on consumers' evaluations and purchase intentions. Journal of retailing, 74(3), 331-352.

30. Gujarati, D. N. \& Porter, D. C (2009). Basic Economrtrics. New York. Mc Graw Hill International Edition.

31. Hoch, S. J., Montgomery, A. L., \& Park, Y. H. (2002). Why private labels show long-term market evolution. Marketing Department Working Paper, University of Pennsylvania.

32. Katsanis, L. P. \& Pitta, D. A. (1995). Punctuated equilibrium and the evolution of the product manager. Journal of Product and Brand Management, 4(3), 49-60.

33. Kumar, A. (2011). Understanding the emerging role of motorcycle in African cities: A political economy perspective. Sub-Saharan Africa Transport Policy Program, Discussion Paper No.13, Urban Transport Series.

34. Kundu, S. \& Kar, M. (2012). An empirical investigation of private label supply by national label producers. Marketing Science, 29(4), 738-755.

35. Kundu, S., Banerjee, S. \& Das, G. (2013). "Understanding the scope of private labels": A case of the organised agri-food retail business. Journal of Agricultural Economics and Development, 2(10), 384-387.

36. Martos-Partal, M. (2012). Innovation and the market share of private labels. Journal of Marketing Management, 28(5-6), 695-715.

37. Miranda, M.J. \& Joshi, M. (2003). Australian retailers need to engage with private label to achieve competitive differences. Asia Pacific Journal of Marketing and Logistics, 15(3), 34-47.

38. Monnot, E., Reniou, F. \& Parguel, B. (undated). Consumer responses to elimination of over-packaging on private label products. 1-30.

39. Nyengerai, S., Jaravaza, D., Mukucha, P., Chirimubwe, R. \& Manjoro, E. (2013). Determinants of Perception towards Private Label Brands in Zimbabwe: The Role of Familiarity, Store Image, Demographic Factors and Consumer Characteristics. Greener Journal of Business and Management Studies, 3(5), 224-230. 
40. Olise, M. C., Nkamnebe, A. D., Ukenna, S. \& Okoli, M. I. (2014). Challenges and Success Drivers of Motorcycle Spare-Parts Private Label Brands in Southeast Nigeria. European Journal of Business and Social Sciences, 3(5), 12-22.

41. Sinha, I. \& Batra, R. (1999). The effect of consumer price consciousness on private label purchase. International Journal of Research in Marketing, 16(2), 237-251.

42. Sirieix, L., Delanchy, M., Remaud, H. \& Zepedad, L. (2011). How do consumers react in front of individual and combined sustainable food labels? A UK focus group study. Working-Paper - UMR MOISA.

43. Song, W. (2009). An Empirical Investigation Of Manufacturing Chinese Private Labels. Journal of Management and Marketing Research, 12 (23).

44. Tamilia, R.D., Corriveau, G. \& Arguedas, L.E. (2000). Understanding the significance of private brands with particular reference to the Canadian grocery market. Workshop Paper No.11, University of Quebec, Montreal, 1-38.

45. Taro Y. (1967). Statistics: An Introductory Analysis.USA. Harper \& Row. International edition.

46. Terpstra, V. \& Sarathy, R. (1994), International Marketing, 6th ed. Chicago IL: The Dryen Press.

47. Tushman M.L. \& Romanelli, E. (1994). Private label positioning: quality versus feature differentiation from the national brand. Journal of Retailing, 82: 79-93.

48. Van de Ven, Polley, A.H., Garud, D.E. \& Venkataraman, S. (1999). The innovation journey. New York, NY: Oxford University Press.

49. Wettsten, K., Brosig, S.A., Glauben, D. A., Hannf \& Loy, K. (2009). Pursuing the value-conscious consumer: store brands versus national brand promotions. Journal of Marketing, 65(1), 71-89. 